\title{
Analysis of the course and treatment of toxocariasis in children-a long-term observation
}

\author{
M. Wiśniewska-Ligier • T. Woźniakowska-Gęsicka • \\ J. Sobolewska-Dryjańska • A. Markiewicz-Jóźwiak • \\ M. Wieczorek
}

Received: 17 May 2011 / Accepted: 7 December 2011 /Published online: 29 December 2011

(C) The Author(s) 2011. This article is published with open access at Springerlink.com

\begin{abstract}
Toxocariasis is a helminthozoonotic disease caused by ascarid larvae of Toxocara genus: Toxocara canis and Toxocara cati. In the reported study, the clinical course of toxocariasis and administered therapy were evaluated in 103 children. The majority of the children (68.9\%) were from the rural environment, with a prevalence of boys $(62.1 \%)$. At diagnosis of infection, 36 (35\%) children reported recurrent abdominal pain, 19 (18.4\%) headache, $6(5.8 \%)$ loss of appetite, 2 subfebrile conditions, and 2 arthralgia, Moreover, 23 $(22.3 \%)$ children demonstrated symptoms of atopic diseases; in $30(29.1 \%)$ children, moderate enlargement of lymphatic nodes was noted. In five children (4.9\%), ophthalmic examination revealed unilateral changes in the eye: in two cases retinitis; in one case fibrotic lesions in the vitreous body, complicated 1 year from diagnosis by retinal detachment; and in other children parafoveal lesions and cataract. Only two children with ocular changes at diagnosis reported visual disorders. In $64.3 \%$ of children, eosinophilia was observed. A covert form of the disease was diagnosed in $95.1 \%$ of the children and an ocular form in $4.9 \%$. In all the children, antiparasitic treatment was implemented, repeated several times in some of them. After therapy, the mean titer of specific antibodies, the number of children with abdominal pains and enlarged lymphatic nodes were decreased, while headaches maintained at unchanged levels. In approximately one fourth
\end{abstract}

M. Wiśniewska-Ligier • T. Woźniakowska-Gęsicka ( $\square) \cdot$

J. Sobolewska-Dryjańska • A. Markiewicz-Jóźwiak •

M. Wieczorek

3rd Department of Paediatrics,

Polish Mother's Memorial Hospital, Research Institute,

Str. Rzgowska 281/289,

93-338, Lodz, Poland

e-mail: 3klinikaped@gmail.com of the children with negative results of antibodies after the therapy, the symptoms of the disease were still reported. Evaluation of the efficacy of treatment is not easy due to non-characteristic symptoms and low kinetics of specific anti Toxocara IgG decrease; however, high IgG titers suggest noneffective treatment of concomitant infection requiring subsequent therapy. Due to risk of ocular form, which may develop in any stage of the disease, irrespectively of specific antibodies concentrations, it seems justified to implement antiparasitic treatment in all children infected with $T$. canis.

\section{Introduction}

Toxocariasis is a helminthozoonotic disease caused by ascarid larvae of Toxocara genus prevalent in dogs (Toxocara canis) and cats (Toxocara cati) (Beaver et al. 1952; Despommier 2003). The adult form of both ascarids produces eggs, which are passed in the feces into the environment. The main source of $T$. canis eggs are young dogs which become infected mainly via transplacental transmission (Gillespie 2001). Men may become accidental hosts of these parasites, infected with eggs from contaminated soil, sand pits, undercooked contaminated meat, and liver (Okulewicz and Złotorzycka 1997). Also, contact with fur and feces of young infected cats and dogs and wild animals may be source of the disease (Roddie et al. 2008). The risk of Toxocara infection increases in proportion with environmental contamination (Alderete et al. 2003; Conde Garcia et al. 1998). Important risk factors of Toxocara transmission include keeping dogs, geophagia (Fan et al. 2005; Luzna-Lyskov 2000), age, sex, geographical location, and poor socioeconomical status (Campos Júnior et al. 2003; Fillaux et al. 2007). The prevalence of serological markers of 
T. canis infection in Western countries ranges between $2 \%$ and 37\% (Magnaval et al. 2001), in tropical countries the seroprevalence is much higher and may reach even $92.8 \%$ (Chomel et al. 1993; Magnaval et al. 1994), while in Poland in selected populations it ranges between $20.7 \%$ and $46.6 \%$ (Wnukowska et al. 2003; Hermanowska-Szpakowicz et al. 2001; Cielecka et al. 2003).

The developmental cycle of $T$. canis in men begins with ingestion of infective eggs containing larvae. The embryonated eggs hatch in the duodenum, where released larvae perforate the small intestine wall and with the blood stream migrate to the liver, lungs, muscles, heart, and sometimes also eye and CNS (Wilder 1950; Dent et al. 1956; Schantz 1989; Glickman and Schantz 1981). The severity of the disease in humans depends not only on the intensity of infection and sites of perforation but also on the intensity of inflammatory response of the host. Inflammatory reaction is a result of immunological response to secretory-excretory antigens of the larvae, which are a mixture of glycoproteins containing a component TBA-1 with potential immunogenic properties (Sugane and Oshima 1983). In infected hosts, the level of immunoglobulins IgG, $\operatorname{IgM}$, and in particular IgE increases, accompanied by eosinophilia (Buijs et al. 1995). In the majority of cases in humans, the disease is either covert or asymptomatic (Glickman and Shofer 1987; Magnaval et al. 1994; Bass et al. 1983; Bass et al. 1987). Clinical manifestation usually is visceral or ocular (Schantz 1989). The visceral form is caused by the migration of larvae through large organs and is characterized by fever, joint and muscle pain, abdominal pain, enlargement of lymphatic nodes, and hepatosplenomegaly; sometimes it may lead to aseptic eozynophilic encephalomeningitis, encephalitis, and epilepsy. Visceral form also presents as inflammation of the joints, rash, eosinophilic inflammation of subdermal tissue, eosinophilic pneumonia, and endocarditis (Humbert et al. 2000; Figueiredo et al. 2005; Gavignet et al. 2008). Ocular form typically occurs in older children and young adults. Infestation in the eye leads to endophthalmitis with retinal detachment, retinal granulomatous lesions, proliferation, uveitis, papillitis, and as a result visual loss (Schantz 1989).

The diagnosis is confirmed by the presence of specific antibodies, mainly of the IgG class-Toxocara excretory-secretory antigens (TES-Ag) — characteristic for stage II larvae, detected by ELISA method (Jacquier et al. 1991) and verified by the Western blot test (Magnaval et al. 1991). Recently, determination of specific IgE antibodies concentration has also been introduced; IgE antibodies level may be increased at normal level of $\mathrm{IgG}$ antibodies and with lack of clinical symptoms (Magnaval et al. 1992; Uhlíková et al. 1996). Because of high incidence of $T$. canis infection in children, risk of development of clinically serious forms of the disease, and lack of clear diagnostic criteria of the active phase of the disease and its cure, we conducted studies aimed at analysis of the clinical course and efficacy of treatment in long-term observation.

\section{Material and methods}

The study comprised 103 children treated for toxocariasis at the Zoonotic Diseases Outpatient Office, Mother's Memorial Hospital (ICZMP) in Łódź, between 2003 and 2009. In all children, the diagnosis was confirmed by immunoserological test ELISA, aimed at detection of specific IgG antibodies against TES-Ag, characteristic for stage II larvae of T. canis (commercial test from Bordier Affinity Products, Switzerland). Absorbance was measured at $405 \mathrm{~nm}$ using PR 2100 Sanofi Diagnostics Pasteur spectrophotometer. According to the producer's data, specificity of the test is assumed to be $86 \%$ and sensitivity $91 \%$ (Jacquier et al. 1991). The results were assumed to be negative when the absorbance of the analyzed serum was higher than weak positive control. The results were presented as percentages, where values $0-28 \%$ represent absorbance of the negative control, 28-32\% weak positive, and 32-100\% positive control. Values between $32 \%$ and $100 \%$ confirmed $T$. canis infection. Serological tests were performed in the Department of Clinical Microbiology, ICZMP, in Łódź.

In all children history, physical examination results and serological tests results for $T$. canis infection were analyzed, as well as ophthalmic examination and implemented treatment. Laboratory test results such as full blood count (with percentage of eosinophils in peripheral blood smear), liver tests, total $\mathrm{IgE}$, tests toward other microorganisms infection, imaging studies, and consultations in clinically justified cases were also taken into consideration.

\section{Statistical analysis}

The obtained results were used to calculate mean values $(x)$ and SD. For statistical analysis, specific antibodies titers below $28 \%$ were accepted as $28 \%$ and $>100 \%$ as $100 \%$. Statistical significance was evaluated by nonparametrical tests-MannWhitney $U$ test for independent variables and Wilcoxon test for dependent variables. Significance level was adopted at $p \leq$ 0.05 . For selected values, correlation was described by Pearson linear correlation coefficients, with determination of significance and linear regression equations. Parameters of linear regression were calculated by the smallest squares method. The statistical analysis was performed using STATISTICA 5.0 PL program.

\section{Results}

Age, sex, and place of residence

Mean age of the analyzed children was 7.3 \pm 3.4 lat (max 14.7, min 1.4 years). In the studied group, male sex prevailed (64 boys, 39 girls; $p<0.05$ ). 
The infected children significantly more frequently were of rural than urban origin (respectively 71 and 32 children; $p<0.001)$. Among 32 city dwelling children, 12 came from large cities, with over 200,000 inhabitants (Łódź, Wrocław, Częstochowa) and 20 from cities with number of inhabitants ranging between 12,000-100,000 (Skierniewice, Tomaszów Mazowiecki, Piotrków Trybunalski, Opoczno, Radomsko, Wieluń, Łowicz, Zgierz, Pabianice, Kutno, Koluszki, Brzeziny) (Table 1).

\section{Clinical symptoms}

During the first visit at the Outpatient Office, $36(35 \%)$ children reported recurrent abdominal pain, 19 (18.4\%) headache, $6(5.8 \%)$ loss of appetite, 2 subfebrile conditions, and 2 arthralgia, Moreover, 23 (22.3\%) children demonstrated symptoms of atopic diseases ( 2 cases of bronchial asthma, 7 cases of recurrent rash, 3 cases of food allergy, 19 cases of high $\mathrm{IgE}$ levels).

On physical examination in 30 (29.1\%) children, moderate enlargement of lymphatic nodes was noted (in 4 cases of cervical and axillary nodes, in 18 cases of cervical nodes, in 6 cases of submandibular nodes, in 2 cases of axillary nodes) and in one child abdominal tenderness. In five children (4.9\%), ophthalmic examination revealed unilateral changes in the eye: in two cases retinitis; in one case fibrotic lesions in the vitreous body, complicated 1 year from diagnosis by retinal detachment; and in other children parafoveal lesions and cataract. Only two children with ocular changes at diagnosis reported visual disorders.

At diagnosis of infection in 45 (from 70 available studies$64.3 \%$ ) children, eosinophilia (increased number of eosinophils in peripheral blood smear above $5 \%$ of all leukocytes) was observed. At the onset of observation, mean eosinophil count was $9.9 \pm 8.5 \%(\max 34 \%)$. In one child, mild anemia was noted (Table 2).

In the studied group in 98 (95.1\%) children, covert form of the disease was diagnosed and in five (4.9\%) ocular form. In 27 children $(26.2 \%)$, the only reason for toxocariasis diagnostic

Table 1 Characteristic of the study group children in terms of age, sex, and place of residence

\begin{tabular}{llcl}
\hline & & $\begin{array}{l}\text { Number of children } \\
(N=103)\end{array}$ & $\begin{array}{l}\% \text { of } \\
\text { children }\end{array}$ \\
\hline $\begin{array}{c}\text { Age (years), } \\
\text { medium } \pm \text { SD } \\
(\text { min; max })\end{array}$ & $7.3 \pm 3.4(1.4 ; 14.7)$ & & \\
Sex & Female & 39 & 37.9 \\
& Male & 64 & 62.1 \\
$\begin{array}{c}\text { Place of } \\
\text { residence }\end{array}$ & Town $>200,000$ population & 12 & 11.7 \\
& Town $<100,000$ population & 20 & 19.4 \\
& Village & 71 & 68.9 \\
\hline
\end{tabular}

Table 2 An analysis of clinical symptoms in the analyzed group of children with toxocariasis

\begin{tabular}{lcc}
\hline Clinical symptoms & Number of children & \% of children \\
\hline Subfebrile conditions & 2 & 1.9 \\
Abdominal pain & 36 & 35 \\
Headache & 6 & 18.4 \\
Loss of appetite & 2 & 5.8 \\
Arthralgia & 23 & 1.9 \\
A history of allergic symptoms & $1 / 103$ & 22.3 \\
Abdominal tenderness & 30 & 1 \\
Enlargement of lymphatic nodes & 22 & 29.1 \\
Cervical & 6 & \\
Submandibular & 6 & \\
Axillary & 5 & 4.9 \\
Changes in the eye & 45 & 64.3 \\
Eosinophilia at infection & & \\
$\quad$ diagnosis (studies available & & \\
$\quad$ in 70 children) & 1 & \\
Mild anemia &
\end{tabular}

was eosinophilia observed during control examinations and/or symptoms of atopic disease. In three cases $(2.9 \%)$, there were no symptoms, and the children were sent for consultation due to the presence of parasitic disease in the family.

Serological tests

Mean titer of antibodies against $T$. canis at diagnosis was $82.1 \pm$ $23.9 \%$, while 55 children $(53.4 \%$ ) showed titers $>100 \%$.

\section{Treatment}

In all 103 children, antiparasitic treatment was implemented. Some children required repeated courses: Within the analyzed time span in 103 children, 72 were qualified for two courses, 46 for three courses, and 40 for more. Treatment regime was created on an individual basis. The following antihelmintics were used: albendazole (Zentel) for 3-5 days or albendazole for 3 days and then after 3 weeks mebendazole (Vermox) for 3 days, or 6 days of mebendazole. Albendazole was administered in the dose of $400 \mathrm{mg} / \mathrm{day}$ and mebendazole in the dose of 100-200 mg/day. Ocular forms of toxocariasis were treated in cooperation with ophthalmologists, and several courses of treatment were used, i.e., thiabendazole (Mintezol $50 \mathrm{mg} / \mathrm{kg} /$ day for 7 days), albendazole, and/or mebendazole in combination with steroids.

The number of applied treatment courses depended on patient's place of residence

Analysis of the number of antiparasitic therapy courses and residence place showed that $69 \%$ of children from rural areas 
required two courses of antihelmintic treatment, and $50.7 \%$ required three courses, while in children from urban areas, the numbers were $58.3 \%$ and $16.7 \%$, respectively (Table 3 ).

Serological tests after subsequent treatment courses

After course 1 of treatment, on the average after $178.4 \pm$ 114.7 days ( $\min 14$, max 591, median 139 days) in the studied group, the mean titer of specific antibodies against $T$. canis significantly decreased to $69.7 \pm 29.8 \%(p<0.001)$; negative results were observed in $18(17.5 \%)$ patients, and in 38 (36.9\%) titers exceeded $100 \%$.

In the group of 72 children qualified for the second course of antihelmintics, before course 2 , mean titer of antibodies was $84.0 \pm 21.5 \%$, and in $39(54.2 \%)$ children, it exceeded $100 \%$. After the second course in the studies conducted after $230.6 \pm$ 163.8 days, the titer significantly decreased to $67.5 \pm 28.5 \%(p<$ $0.001)-11(15.2 \%)$ children had negative titers and 21 (29.1\%) children $>100 \%$.

In the group of 46 children qualified for the third course, before course 3 , mean titer of specific antibodies was $82.5 \pm$ $20.7 \%-23(50 \%)$ children showed titer $>100 \%$. In the study conducted $305 \pm 411$ days after course 3 , the titer significantly decreased to $70.4 \pm 29.2 \%(p<0.05)-15(32.6 \%)$ children showed titer $>100 \%$ and six (13\%) children had negative results.

Clinical symptoms after subsequent treatment courses

The analysis of clinical symptoms in the whole group showed a decrease - after treatment — of the percentage of children with abdominal pain (mainly after course 3 ) and enlargement of lymphatic nodes (mainly after course 1 and 3) (Table 4). Among children with negative results of antibodies against $T$. canis after course 1, in four cases (21.1\%) headaches persisted, in five $(26.3 \%)$ cases abdominal pain, and in three $(15.8 \%)$ lymphatic nodes enlargement (Table 5).

After the first course eosinophil count in the whole group significantly decreased $(p<0.05)$ from $9.9 \pm 8.5 \%$ to $7.6 \pm$ $6.1 \%$, and after the second and third course, mean eosinophil count showed a lowering tendency (from $8.7 \pm 6.3 \%$ to $7.9 \pm$ $6.4 \%$ and from $9.1 \pm 7.0 \%$ to $7.7 \pm 5.6 \%$, respectively).
The dynamic of antibody and eosinophil titer reduction in course of therapy

In the studied group of children, we observed a subgroup in which after antiparasitic treatment (after courses 1,2, or 3 ) in subsequent serological test toward toxocariasis results were negative and a subgroup in which the results were highly positive (>100\%). In Table 6, we present selected parameters in subgroups. Statistical analysis revealed significantly lower titer of antibodies against $T$. canis before treatment (before courses 1,2, and 3 ) in children in whom after treatment results were negative, as compared to children in whom results after therapy were highly positive.

The statistical analysis conducted in the group of children in whom after treatment titer of specific antibodies decreased showed, during all three courses of treatment, positive correlation between the degree of titer decrease (difference of antibodies titer before and after therapy) and titer before treatment, but no correlation between the degree of titer decrease (difference of antibodies titer before and after therapy) and time span that elapsed to titer determination. Similarly, in children in whom eosinophil count decreased after therapy, during all three courses of treatment, a positive correlation was between the difference in eosinophil count after treatment and eosinophil count before treatment. There was no correlation between specific antibodies titer and eosinophil count, both in studies performed before and after subsequent courses of treatment (Tables 7 and 8).

\section{Discussion}

Toxocariasis belongs to most common parasitic zoonotic diseases worldwide. Positive serological tests toward Toxocara are particularly common in developing countries, especially in rural areas and some tropical islands, where they may even reach 92.8\% (La Reunion) (Magnaval et al. 1994). In western countries, the occurrence of positive serological markers for Toxocara is estimated at $2-5 \%$ in industrial areas and $14.2-$ $37 \%$ in rural areas (Magnaval et al. 2001).

There are no data concerning the occurrence of $T$. canis infection in Poland. Studies conducted in selected populations of children and adolescents reveal the presence of

Table 3 An analysis of the number of antiparasitic treatments vs. the place of residence

\begin{tabular}{lccc}
\hline & $\begin{array}{c}\text { 1st treatment course } \\
\text { Number of children (\%) }\end{array}$ & $\begin{array}{c}\text { 2nd treatment course } \\
\text { Number of children (\%) }\end{array}$ & $\begin{array}{c}\text { 3rd treatment course } \\
\text { Number of children (\%) }\end{array}$ \\
\hline Children - inhabitants of towns with $>200,000$ population $(N=12)$ & $12(100 \%)$ & $7(58.3 \%)$ & $2(16.7)^{*}$ \\
Children -inhabitants of towns with $<100,000$ population $(N=20)$ & $20(100 \%)$ & $16(80 \%)$ & $8(40 \%)$ \\
Children living in the village $(\mathrm{N}=71)$ & $71(100 \%)$ & $49(69 \%)$ & $36(50.7 \%)^{*}$ \\
\hline
\end{tabular}

${ }^{*} p<0.05$ (values differ significantly) 
Table 4 An analysis of the occurrence of selected clinical symptoms before and after particular antiparasitic treatment course

\begin{tabular}{|c|c|c|c|c|c|c|}
\hline \multirow[t]{3}{*}{ Clinical symptoms } & \multicolumn{2}{|c|}{$\begin{array}{l}\text { 1st treatment course } \\
\text { (number of children) }\end{array}$} & \multicolumn{2}{|c|}{$\begin{array}{l}\text { 2nd treatment course } \\
\text { (number of children) }\end{array}$} & \multicolumn{2}{|c|}{$\begin{array}{l}\text { 3rd treatment course } \\
\text { (number of children) }\end{array}$} \\
\hline & \multicolumn{2}{|l|}{$N=103$} & \multicolumn{2}{|l|}{$N=72$} & \multicolumn{2}{|l|}{$N=46$} \\
\hline & Before therapy & After therapy & Before therapy & After therapy & Before $t$ therapy & After therapy \\
\hline Abdominal pain & $36(35 \%)$ & $29(29.1 \%)$ & $17(23.6 \%)$ & $9(12.5 \%)$ & $11(23.9 \%)^{*}$ & $4(8.7 \%)^{*}$ \\
\hline Headache & $19(18.4 \%)$ & $18(18.4)$ & $9(12.5 \%)$ & $6(8.3 \%)$ & $4(8.7 \%)$ & $1(2.2 \%)$ \\
\hline Loss of appetite & $6(5.8 \%)$ & $4(3.9 \%)$ & $5(5.6 \%)$ & $3(2.8 \%)$ & $2(4.3 \%)$ & $3(6.5 \%)$ \\
\hline Enlargement of lymphatic nodes & $30(29.1 \%)^{*}$ & $18(17.5 \%)^{*}$ & $15(20.8 \%)$ & $14(19.4 \%)$ & $13(28.3)^{*}$ & $4(8.7 \%)^{*}$ \\
\hline
\end{tabular}

${ }^{*} p<0.05$ (values differ statistically significant before and after treatment)

positive serological markers in $25.9-46.6 \%$ in Mazowieckie district (Wnukowska et al. 2003), 43\% in Łódź district (Cielecka et al. 2003), and 20.7\% in Podlaskie district (Hermanowska-Szpakowicz et al. 2001).

According to numerous reports, rural environment predisposes to toxocariasis. In France, the incidence of infection in rural populations is estimated at $14.4 \%$, with Turkey at $16.97 \%$, while in urban areas at $4.8 \%$ and $0.71 \%$, respectively (Magnaval and Baixench 1993; Doğan et al. 2007).

Similarly, in the presented study, the majority of patients with $T$. canis infection $(68.9 \%)$ came from rural areas. In some reports on Polish population, the numbers cited for urban children are even higher. Gawor et al. (2008) in their study concentrating on one of the diagnostic centers in the Mazowieckie district found that $65 \%$ of children with diagnosed toxocariasis came from the cities or suburbs. Presented higher incidence of infection in cities could have been connected with higher availability of diagnostic tests in cities, but contamination of the environment cannot be overruled. Following some authors (Mizgajska et al. 2001; Pawłowski and Mizgajska 2002) a higher contamination with Toxocara eggs of soil from the centre of Poznan (53\% of all soil samples) than soil from rural and suburban recreation centers was stressed. The situation is similar in Kraków and its surroundings, where $57 \%$ of soil samples from the city center showed presence of Toxocara eggs and from rural and recreation areas only 5-16\% (Mizgajska 2000). However, studies of Gawor et al. (2008) in the Mazowieckie district did not confirm higher contamination of soil in the cities but showed that soil from house gardens contained Toxocara eggs more frequently than playgrounds and sand pits for children both in the cities and small villages.

The obtained results should draw attention to the problem of toxocariasis in small cities. Although in the presented study the percentage of children from big and small cities differed only slightly $(11.7 \%$ and $19.4 \%$, respectively), however if the number of children from urban areas was compared to the number of inhabitants in their respective cities (Central Statistical and Information 2009), one child from the Centre would correspond to 200,000 children from big cities and about 25,000 children from small cities.

Toxocariasis is mainly a childhood disease, due to close contacts of children with animals, playing in sand pits contaminated with cats and dogs excrements, failure to observe hygiene, and tendency to put dirty hands in the mouth. However, some authors draw attention to the frequent occurrence of positive serological reactions in people over 60 years old (Gueglio et al. 1994), as well as in farmers, veterinarians, slaughterhouse staff, and hunters (Deutz et al. 2005). In studies of Deutz et al. (2005), having a dog or cat by farmers and slaughterhouse staff was a risk factor of toxocariasis. In the conducted study, the average age of children was 7.3 years (similar in both sexes). In the study group, boys prevailed, which results from their habits of spending free time, mainly outdoors, and failure to observe even basic hygiene.

Table 5 An analysis of selected clinical symptoms in children with a negative titer of antibodies against $T$. canis after treatment

\begin{tabular}{|c|c|c|c|c|c|c|}
\hline \multirow[t]{2}{*}{ Clinical findings } & \multicolumn{2}{|c|}{ 1st treatment course $(N=19)$} & \multicolumn{2}{|c|}{2 nd treatment course $(N=11)$} & \multicolumn{2}{|c|}{3 rd treatment course $(N=6)$} \\
\hline & Before therapy & After therapy & Before therapy & After therapy & Before therapy & After therapy \\
\hline Headache & $5(26.3 \%)$ & $4(21.1 \%)$ & $3(27.3 \%)$ & $2(18.2 \%)$ & $1(16.7 \%)$ & $1(16.7 \%)$ \\
\hline Abdominal pain & $9(47.4 \%)$ & $5(26.3 \%)$ & 0 & 0 & 0 & 0 \\
\hline Loss of appetite & $1(5.3 \%)$ & 0 & $1(9.1 \%)$ & $1(9.1 \%)$ & 0 & 0 \\
\hline Enlargement of lymphatic nodes & $8(41.1 \%)$ & $3(15.8 \%)$ & $4(36.4 \%)$ & $1(9.1 \%)$ & $1(16.7 \%)$ & 0 \\
\hline
\end{tabular}


Table 6 An analysis of selected parameters in children with a negative titer of antibodies against $T$. canis after treatment

\begin{tabular}{|c|c|c|c|c|c|c|}
\hline & $\begin{array}{l}\text { Antibody titer } \\
\text { before therapy } \\
(\%)(\text { medium } \pm \mathrm{SD})\end{array}$ & $\begin{array}{l}\text { Antibody titer } \\
\text { after therapy }(\%) \\
(\text { medium } \pm \mathrm{SD})\end{array}$ & $\begin{array}{l}\text { The number of days from } \\
\text { therapy onset to antibody } \\
\text { titer assessment (medium } \pm \mathrm{SD} \text { ) }\end{array}$ & $\begin{array}{l}\text { The number of days from } \\
\text { the } 1^{\text {st }} \text { therapy to antibody } \\
\text { titer assessment (medium } \pm \mathrm{SD} \text { ) }\end{array}$ & $\begin{array}{l}\text { Eosinophilia } \\
\text { before therapy } \\
\text { (medium } \pm \mathrm{SD} \text { ) }\end{array}$ & $\begin{array}{l}\text { Eosinophilia } \\
\text { after therapy } \\
(\text { medium } \pm \mathrm{SD})\end{array}$ \\
\hline 1st therapy, $N=19$ & $70.2 \% \pm 27$ & $<28$ & $183 \pm 110$ & $183 \pm 110$ & $8.5 \pm 5.7$ & $4.8 \pm 3.5$ \\
\hline 2nd therapy, $N=11$ & $73.1 \% \pm 22.8$ & $<28$ & $304.2 \pm 211.8$ & $527 \pm 350.7$ & $5.7 \pm 1.9$ & $5.5 \pm 3.5$ \\
\hline 3rd therapy, $N=6$ & $69 \% \pm 23.6$ & $<28$ & $252.2 \pm 141.5$ & $719.8 \pm 190.9$ & $8 \pm 6.9$ & $5.2 \pm 3$ \\
\hline
\end{tabular}

Manifestation of toxocariasis is varied and non-characteristic, in many instances also asymptomatic (Pawlowski 2001). In the studied group of children, in $95.1 \%$ of cases covert form of the disease was diagnosed and in $4.9 \%$ the ocular form.

In the group of children with covert form of disease, in three cases the only cause for contacting a doctor was toxocariasis diagnosed in the close environment of the child. In $26.2 \%$ of children, diagnostics toward parasitic disease was initiated because of positive allergic history or eosinophilia. In the study of Dobosz et al. (2007) in as many as $28 \%$ of children with diagnosed toxocariasis diagnostic tests were done because the children's siblings were infected with Toxocara, and in 46\% of children eosinophilia, high IgE titer or anemia observed in laboratory tests performed for other reasons. Similarly, Despommier (2003) in their study found that in 50\% of children toxocariasis was suspected only because of eosinophilia, elevated $\operatorname{IgE}$ serum concentration, or anemia. The role of eosinophil cells in fighting infection is less understood than in other helminthozoonotic diseases and appears to play less significant role, probably due to the development of Toxocara various defense mechanisms against the host immune response. According to Horak et al. (2005), the excessive peripheral eosinophilia is a result from successful host manipulation by parasite, leading to host's inability to develop adequate inflammatory response. They also point out that it should not be correlated with the antiparasite response in larval toxocariasis.

In the analyzed group of children, the most common complaint was abdominal pain ( $35 \%$ of cases). It is noteworthy that this symptom is by far the most common, though not pathognomonic, symptom of all childhood diseases. Antiparasitic treatment brings relief of this symptom, which confirms the connection between Toxocara infection and abdominal pain in the studied group of children; however, in some children, the symptom persists despite normalization of serological parameters of infection, which necessitates further diagnostics and differentiation.

Mild enlargement of lymphatic nodes is present in about $30 \%$ of children, which seems to be similar as in general population. Studies conducted within All-Polish Prophylactic Ultrasound Survey in much younger children, 9-24 months, reveal lymphatic nodes enlargement of reactive type in 52.4\% of cases (Madej et al. 2007). However, decrease in nodes size after treatment, similarly as abdominal pain, may suggest $T$. canis etiology.

Headaches are quite common in the studied group of children and oftentimes are reason for diagnostics towards toxocariasis. It is noteworthy that in long-term observation the occurrence of headaches did not decrease despite treatment, also in children with negative serological markers of infection. This observation diminishes the value of this symptom in the latent form of $T$. canis infection, even though cerebral form of the disease should always be taken into account. There are about 30 available case reports on neurotoxocariasis connected with location of the larvae in the CNS; however, allergic reactions to $T$. canis antigens may also lead to neurological abnormalities (Osoegawa et al. 2004).

Numerous reports indicate that $T$. canis infection may increase the risk of episodic wheezing in some populations, which may result from host response to parasitic infestation or from Th2-type reaction to inhaled allergens, stimulated by $T$.

Table 7 Correlations between the reduction of antibodies against T. canis after treatment and the level of antibodies before treatment in particular antiparasitic treatment courses

\begin{tabular}{|c|c|c|c|c|c|c|}
\hline & \multicolumn{2}{|c|}{$\begin{array}{l}\text { Difference between antibody } \\
\text { titers before and after the } 1 \text { st } \\
\text { treatment course }\end{array}$} & \multicolumn{2}{|c|}{$\begin{array}{l}\text { Difference between antibody } \\
\text { titers before and after the } 2 \text { nd } \\
\text { treatment course }\end{array}$} & \multicolumn{2}{|c|}{$\begin{array}{l}\text { Difference between antibody } \\
\text { titers before and after the } 3 \mathrm{rd} \\
\text { treatment course }\end{array}$} \\
\hline & $r$ & $p$ & $r$ & $p$ & $r$ & $p$ \\
\hline Antibody titer before 1 st therapy & 0.516 & 9.43E05 & - & - & - & - \\
\hline Antibody titer before 2 nd therapy & - & - & 0.47 & 0.003 & - & - \\
\hline Antibody titer before 3rd therapy & - & - & - & - & 0.59 & 0.001 \\
\hline
\end{tabular}

$r$ Pearson's correlation coefficient, $p$ significance level 
Table 8 Correlations between eosinophil level reduction after treatment and eosinophil level before treatment in three consecutive antiparasitic treatments

\begin{tabular}{|c|c|c|c|c|c|c|}
\hline & \multicolumn{2}{|c|}{$\begin{array}{l}\text { Difference between } \\
\text { eosinophilia before and after } \\
\text { the } 1 \text { st treatment course }\end{array}$} & \multicolumn{2}{|c|}{$\begin{array}{l}\text { Difference between } \\
\text { eosinophilia before and after } \\
\text { the } 2 \text { nd treatment course }\end{array}$} & \multicolumn{2}{|c|}{$\begin{array}{l}\text { Difference between } \\
\text { eosinophilia before and after } \\
\text { the 3rd treatment course }\end{array}$} \\
\hline & $r$ & $p$ & $r$ & $p$ & $r$ & $p$ \\
\hline Percentage of eosinophils before 1 st therapy & 0.78 & 7.47E08 & - & - & - & - \\
\hline Percentage of eosinophils before 2 nd therapy & - & - & 0.53 & 0.005 & - & - \\
\hline Percentage of eosinophils before $3 \mathrm{rd}$ therapy & - & - & - & - & 0.64 & 0.006 \\
\hline
\end{tabular}

$r$ Pearson's correlation coefficient, $p$ significance level

canis (Maizels and Yazdanbakhsh 2003; Cooper 2009). Incidence of positive allergic history in the studied group of children $(22.3 \%)$ was similar to the occurrence of allergy determined by Majkowska-Wojciechowska et al. (2000) in the pediatric population from Łódź. In the above-mentioned study, almost $20 \%$ of children aged $7-15$ reported allergic symptoms from the lower respiratory tract, $30.6 \%$ allergic rhinitis, $9 \%$ food allergy, and $16.4 \%$ various skin reactions. Although some authors suggest a contribution of $T$. canis infection to the allergic sensitization (e.g., Taylor et al. 1988; Buijs et al. 1994; Oteifa et al. 1998; Buijs et al. 1997), our results do not confirm this observation.

Location of the larvae in the eye may lead to irreversible damage up to complete loss of vision, although in some cases it may be asymptomatic, with even no elevation of infection markers. In the studied group, $4.6 \%$ of children had ocular form of the disease. Ocular form appears to be endemic in some areas worldwide - in Alabama, the estimated incidence is one per 100,000 persons (Maetz et al. 1987). However, in studies conducted in France in the early 1990s, none of 401 seropositive individuals was diagnosed as ocular toxocariasis (Gueglio et al. 1994). In the study of Dobosz et al. (2007), $21 \%$ of children toxocariasis involved the eye; however, this group comprised children treated at the Child Memorial Health Institute, which is the national reference center for difficult ophthalmologic cases. Numerous authors stress the prevalence of ocular form in older children and adults. In the presented group, ocular lesions were present in children aged 4-7 years, and the majority of them were boys from rural areas. Contrary to other authors' reports (e.g., Knapen et al. 1983; Juszko et al. 1994; Magnaval et al. 2001), in our group in all children, high titers of specific antibodies were present.

T. canis infection oftentimes is a self-limiting disease; thus, many authors suggest in latent forms, in particular those without eosinophilia, no antiparasitic treatment, just observation, and prophylaxis of concomitant infections (e.g., Magnaval et al. 2001). In the presented group of children due to risk of ocular form, which may develop in all stages of the disease, with low or high specific antibodies levels in all children with T. canis, infection antiparasitic treatment was implemented.
According to many authors, evaluation of the efficacy of treatment is difficult. In asymptomatic forms, the efficacy of therapy may be marked by clinical symptoms disappearance, though is not always correlated with concomitant decrease in serological infection markers. In asymptomatic forms of the disease, the detection of specific anti-Toxocara IgG does not appear to be useful for monitoring therapy, as positive titers seem to be present over a long period of time. According to Bass et al. (1987), when ELISA antibody titers were compared between treated and untreated children, they did not differ significantly as a result of antiparasitic treatment. In the presented group, if high titers of specific antibodies were still detected 6 months after treatment, with presence of eosinophilia and/or other clinical symptoms of toxocariasis, antihelmintic treatment was repeated.

In the studies conducted on average 6,8 , and 10 months from subsequent courses of antiparasitic treatment, mean titers of specific anti-Toxocara IgG significantly decreased in children who received treatment, by $12 \%, 16 \%$, and $12 \%$, respectively. Analysis of individual cases shows that kinetics of antibody titers varies significantly. In some children, titers of about $70 \%$ decreased by over $50 \%$ in the period of 6 months and were negative, but in some children, titers $>100 \%$ remained high (or recurred) despite several courses of antiparasitic treatment. In a 2-year follow-up, the titers $>100 \%$ were still present in about $10 \%$ of cases. The presented data suggest possibility of high kinetics of specific anti-Toxocara IgG decrease and indicate that in resistant cases with persistent high titers, superinfection must be taken into account.

In our material, there was no correlation between the degree of specific anti-Toxocara $\operatorname{IgG}$ decrease and time span after treatment; however, there was a positive correlation with antibodies concentration decrease and concentration level before therapy. We have demonstrated also that high titers of specific anti-Toxocara antibodies were present for a longer time in children from rural areas and from small cities and that in this group of children, repeated antiparasitic therapy courses were necessary more often. The above observation may indicate that persistent high titers of antibodies may be due to superinfection in the place of residence. Similarly in the 
study by Żarnowska et al. (2008) in about $40 \%$ of children from non-contaminated areas 2 years after treatment, specific anti-Toxocara antibody concentration decreased by $50 \%$, in contrast to children from contaminated areas, where no such reaction was noted.

\section{Conclusions}

T. canis infection in children presents which non-characteristic symptoms. Due to risk of ocular form, which may develop in any stage of the disease, irrespectively of specific antibodies concentrations, it seems justified to implement antiparasitic treatment in all children infected with T. canis. Evaluation of the efficacy of treatment is not easy due to non-characteristic symptoms; low kinetics of specific anti-Toxocara IgG decrease; however, high IgG titers suggest non-effective treatment of concomitant infection requiring subsequent therapy.

In conclusion of the above, constant multispecialistic care of patients with $T$. canis infection, widening of indications for repeated antiparasitic therapy, and introduction of new diagnostic methods for detection of new cases, apart from widespread prophylactic efforts, may become a crucial element in the prevention of consequences and complications of toxocariasis.

Open Access This article is distributed under the terms of the Creative Commons Attribution Noncommercial License which permits any noncommercial use, distribution, and reproduction in any medium, provided the original author(s) and source are credited.

\section{References}

Alderete JM, Jacob CM, Pastorino AC, Elefant GR, Castro AP, Fomin AB, Chieffi PP (2003) Prevalence of Toxocara infection in schoolchildren from the Butanta region, Sao Paulo, Brazil. Mem Inst Oswaldo Cruz 98:93-597

Bass JL, Mehta KA, Glickman LT, Blocker R, Eppes BM (1987) Asymptomatic toxocariasis in children. A prospective study and treatment trial. Clin Pediatr (Phila) 26:441-446

Bass JL, Mehta KA, Glickman LT, Eppes BM (1983) Clinically inapparent Toxocara infection in children. N Engl J Med 24:723-724

Beaver PC, Snyder CH, Carrera GM, Dent JH, Lafferty JW (1952) Chronic eosinophilia due to visceral larva migrans: report of three cases. Pediatrics 9:7-19

Buijs J, Borsboom G, Renting M, Hilgersom WJ, van Wieringen JC, Jansen G, Neijens J (1997) Relationship between allergic manifestations and Toxocara seropositivity: a cross-sectional study among elementary school children. Eur Respir J 10:1467-1475

Buijs J, Borsboom G, van Gemund JJ, Hazebroek A, van Dongen PA, van Knapen F, Neijens HJ (1994) Toxocara seroprevalence in 5-yearold elementary schoolchildren: relation with allergic asthma. Am J Epidemiol 140:839-847
Buijs J, Egbers MW, Lokhorst WH, Savelkoul HF, Nijkamp FP (1995) Toxocara-induced eosinophilic inflammation. Airway function and effect of anti-IL-5. Am J Respir Critl Care Med 151:873-978

Campos Júnior D, Elefant GR, de Melo e Silva EO, Gandolfi L, Jacob CM, Tofeti A, Pratesi R (2003) Frequency of seropositivity to Toxocara canis in children of different socioeconomic strata. Rev Soc Bras Med Trop 36:509-513

Central Statistical and Information (2009) http://demografia.stat.gov. $\mathrm{pl} /$ BazaDemografia/Tables.aspx

Chomel BB, Kasten R, Adams C, Lambillotte D, Theis J, Goldsmith R, Koss J, Chioino C, Widjana DP, Sutisna P (1993) Serosurvey of some major zoonotic infections in children and teenagers in Bali, Indonesia. Southeast Asian J Trop Med Public Health 24:321-326

Cielecka B, Majda-Stanislawska E, Kuszewski W (2003) Częstość występowania inwazji Toxocara u dzieci w regionie łódzkim i jej znaczenie kliniczne. Materiały Sympozjum "Parazytozyproblemy kliniczne", Białystok, 06.06.2003, 62-63

Conde Garcia L, Muro Alvarez A, Simon Martin F (1998) Epidemiological studies on toxocariasis and visceral larva migrans in a zone of western Spain. Ann Trop Med Parasitol 83:615-620

Cooper PJ (2009) Interactions between helminth parasites and allergy. Curr Opin Allergy Clin Immunol 9:29-37

Dent DH, Nichols RL, Beaver PC, Carrera GM, Staggers RJ (1956) Visceral larva migrans with case report. Am J Pathol 32:777-803

Despommier D (2003) Toxocariasis: clinical aspects, epidemiology, medical ecology, and molecular aspects. Clin Microbiol Rev 16:265-272

Deutz A, Fuchs K, Auer H, Kerbl U, Aspöck H, Kofer J (2005) Toxocara-infestations in Austria: a study on the risk of infection of farmers, slaughterhouse staff, hunters and veterinarians. Parasitol Res 97:390-394

Dobosz S, Marczynska M, Popielska J, Żarnowska-Prymek H (2007) Toksokaroza u dzieci w Polsce-powód diagnostyki i objawy kliniczne. Ped Wsp Gastroenterol Hepatol Żywienie Dziecka 9:247-250

Doğan N, Dinleyici EC, Bor O, Töz SO, Ozbel Y (2007) Seroepidemiological survey for Toxocara canis infection in the northwestern part of Turkey. Türkiye Parazitol Der 31:288-291

Fan CK, Liao CW, Kao TC, Li MH, Du WY, Su KE (2005) Seroepidemiology of Toxocara canis infection among aboriginal schoolchildren in the mountainous areas of north-eastern Taiwan. Ann Trop Med Parasitol 99:593-600

Figueiredo SD, Taddei JA, Menezes JJ, Novo NF, Silva EO, Cristovao HL, Cury MC (2005) Clinical-epidemiological study of toxocariasis in a pediatric population. J Pediatr (Rio J) 81:126-132

Fillaux J, Santillan G, Magnaval JF, Jensen O, Larrieu E, Sobrino-Becaria CD (2007) Epidemiology of toxocariasis in a steppe environment: the Patagonia study. Am J Trop Med Hyg 76:1144-1147

Gavignet B, Piarroux R, Aubin F, Millon L, Humbert P (2008) Cutaneous manifestations of human toxocariasis. J Am Acad Dermatol 59:1031-1042

Gawor J, Borecka A, Dobosz S, Marczyńska M, Zarnowska-Prymek H, Trzebicka A, Juszko J (2008) Toksokaroza dzieci-trudny problem kliniczny. Przegl Epidemiol 62:407-413

Gillespie S (2001) Toxocara: dogwalking and playing fields. $\mathrm{Br} \mathrm{J}$ Sports Med 35:6-7

Glickman LT, Schantz PM (1981) Epidemiology and pathogenesis of zoonotic toxocariasis. Epidemiol Rev 3:230-250

Glickman LT, Shofer FS (1987) Zoonotic visceral and ocular larva migrans. Vet Clin North Am Small Anim Pract 17:39-53

Gueglio B, Gentile L, Nguyen JM, Achard J, Chabasse D, Marjolet M (1994) Epidemiologic approach to human toxocariasis in western France. Parasitol Res 80:531-536 
Hermanowska-Szpakowicz T, Kondrusik M, Swierzbińska R, Zajkowska J, Pancewicz S (2001) Incidence of antibody detection against Toxocara canis and clinical symptoms in inhabitants of northeastern Poland. Pol Merkur Lekarski 10:168-170

Horak P, Tummeleht L, Talvik H (2005) Predictors and markers of resistance to neurotropic nematode infection in rodent host. Parasitol Res 98:396-402

Humbert P, Niezborala M, Salembier R, Aubin F, Piarroux R, Buchet S, Barale T (2000) Skin manifestations associated with toxocariasis: a case-control study. Dermatology 201:230-234

Jacquier P, Gottstein B, Stingelin Y, Eckert J (1991) Immunodiagnosis of toxocarosis in humans: evaluation of a new enzyme-linked immunosorbent assay kit. J Clin Microbiol 29:1831-1835

Juszko J, Marczyńska M, Zarnowska H (1994) Diagnostyka i leczenie postaci ocznej infekcji larwa glisty psiej Toxocara canis. Klin Oczna 96:275-280

Knapen F, Leusden J, Polderman AM, Franchimont JH (1983) Visceral larva migrans: examinations by means of enzyme-linked immunosorbent assay of human sera for antibodies to excretory-secretory antigens of the second-stage larvae of Toxocara canis. Parasitol Res 69:113-118

Luzna-Lyskov A (2000) Toxocarosis in children living in a highly contaminated area. An epidemiological and clinical study. Acta Parasitol 45:40-42

Madej T, Jędrzejewski G, Woźniak M, Kryza R, Zielonka E, Wieczorek P (2007) Sprawozdanie z badań prowadzonych w ramach Ogólnopolskiego Programu Profilaktycznych Badań Ultrasonograficznych. Pol Przegl Radiol 72(suppl 1):S142-S142

Maetz HM, Kleinstein RN, Federico D, Wayne J (1987) Estimated prevalence of ocular toxoplasmosis and toxocariasis in Alabama. J Infect Dis $156: 414$

Magnaval JF, Baixench MT (1993) Toxocariasis in the Midi-Pyrénées region. In: Lewi JW, Maizels RM (eds) Toxocara and toxocariasis. British Society for Parasitology, London, pp 63-69

Magnaval JF, Fabre R, Maurières P, Charlet JP, de Larrard B (1991) Application of the western blotting procedure for the immunodiagnosis of human toxocariasis. Parasitol Res 77:697-702

Magnaval JF, Fabre R, Maurières P, Charlet JP, de Larrard B (1992) Evaluation of an immunoenzymatic assay detecting specific antiToxocara immunoglobulin E for diagnosis and posttreatment follow-up of human toxocariasis. J Clin Microbiol 30:2269-2274

Magnaval JF, Glickman LT, Dorchies P, Morassin B (2001) Highlights of human toxocariasis. Korean J Parasitol 39:1-11

Magnaval JF, Michault A, Calon N, Charlet JP (1994) Epidemiology of human toxocariasis in La Réunion. Trans R Soc Trop Med Hyg $88: 531-533$
Maizels RM, Yazdanbakhsh M (2003) Immune regulation by helminth parasites: cellular and molecular mechanisms. Nat Rev Immunol 3:733-744

Majkowska-Wojciechowska B, Laskowska B, Wojciechowski Z, Kowalski ML (2000) Występowanie alergii wśród dzieci łódzkich szkól podstawowych: związek z warunkami środowiska domowego i szkolnego. Alergia Astma Immunologia 5:115-122

Mizgajska H (2000) Zanieczyszczenie gleby jajami Toxocara spp. Na terenie Krakowa i pobliskich wsi. Wiad Parazytol 46:105-110

Mizgajska H, Jarosz W, Rejmenciak A (2001) Rozmieszczenie źródeł inwazji Toxocara spp. wśrodowisku miejskim i wiejskim w Polsce. Wiad Parazytol 47:399-404

Okulewicz A, Złotorzycka J (1997) Toxocara canis (Nematoda) oraz toksokarozy zwierząt i człowieka. Wiad Parazytol 43:3-25

Osoegawa M (2004) Diagnosis and treatment of CNS parasite infection with special reference to parasitic myelitis. Rinsho Shinkeigaku 44:961-964

Oteifa NM, Moustafa MA, Elgozamy BM (1998) Toxocariasis as a possible cause of allergic diseases in children. J Egypt Soc Parasitol 28:365-372

Pawlowski Z (2001) Toxocariasis in humans: clinical expression and treatment dilemma. J Helminthol 75:299-305

Pawłowski ZS, Mizgajska H (2002) Toksokaroza w Wielkopolsce w latach 1990-2000). Przegl Epidemiol 56:559-565

Roddie G, Stafford P, Holland C, Wolfe A (2008) Contamination of dog hair with eggs of Toxocara canis. Vet Parasitol 25:85-93

Schantz PM (1989) Toxocara larva migrans now. Am J Trop Med Hyg 41(suppl 3):S21-S34

Sugane K, Oshima T (1983) Activation of complement in C-reactive protein positive sera by phosphorylcholine-bearing component isolated from parasite extract. Parasite Immunol 5:385-395

Taylor MR, Keane CT, O'Connor P, Mulvihill E, Holland C (1988) The expanded spectrum of toxocaral disease. Lancet 26:692-695

Uhlíková M, Hübner J, Kolárová L, Polácková M (1996) Immunological studies on human larval toxocarosis. Cent Eur J Public Health $4: 242-245$

Wilder HC (1950) Nematode endophthalmitis. Transactions. Am Acad Ophthalmol Otolaryngol 55:99-109

Wnukowska N, Bitkowska E, Dzbeński TH (2003) Serologiczna weryfikacja klinicznych rozpoznań toksokarozy u 1374 osób badanych w latach 1995-2002. Materiały Sympozjum "Parazytozy_problemy kliniczne", Białystok, 06.06.2003, 99

Żarnowska H, Borecka A, Gawor J, Marczyńska M, Dobosz S, Basiak W (2008) A serological and epidemiological evaluation of risk factors for toxocariasis in children in central Poland. J Helminthol $82: 123-127$ 